\title{
Acid Retardation method of separation for closed-circuit processing of alumina-containing raw materials with the use of salt-acid digestion
}

\author{
Khamizov R.Kh. ${ }^{1,2}$, Vlasovskikh N.S. ${ }^{1}$, Moroshkina L.P. ${ }^{1}$, Krachak A.N. ${ }^{2}$, \\ Gruzdeva A.N. ${ }^{2}$, Khamizov S.Kh. ${ }^{1}$ \\ ${ }^{\prime}$ «NewChem Technology», LLC, Moscow \\ ${ }^{2}$ Vernadsky Institute of Geochemistry and Analytical Chemistry of the RAS, Moscow
}

Received 21.11.2017

\begin{abstract}
A brief overview and critical analysis of acid and acid-salt methods for processing alumina raw materials, including high-silica bauxite, nepheline and clay is presented. The basic approaches to the creation of closed and reagent-less or low-reagent-consumption processes are demonstrated. The results obtained in the course of long-term systematic laboratory and bench studies are presented, and they display the prospects for the creation of new technologies for the production of alumina from high silica bauxite and aluminum silicates with the use of different nitrate and sulfate reagents. In the case of using acids, the sorption method of «Acid Retardation» in nano-porous media is shown to be successfully used for recycling them into the process head and to ensure soft conditions for the removal of iron components. This stage is realized with the use of strong base anion exchanger, preliminarily equilibrated with the macro-anion composition of solutions to be processed and washed with water or diluted acid solution. The AR process in three phase systems including organic liquids immiscible with water solutions ("New Chem" method) is also described, a this is also important to provide the complete insulation of concentrated salt solution and to simplify its farther treatment. A circular process with the recovery and consumption of the same amount of salt reagent in each cycle is demonstrated. A comparison of digestion methods is given in terms of the completeness of reagent recycling, the quality of product and the complexity of the process. Advisable conditions for the production of alumina from non-traditional raw with salt-acid decomposition are shown. As it is shown, the most in demand are the processes, which fully or partially can be «inscribed» in modern equipment design and process conditions corresponding to the standard Bayer method or its industrial modifications.
\end{abstract}

Keywords: high-silica bauxite, nepheline, digestion, salt method, Acid Retardation, NewChem method.

\section{Применение разделения методом удерживания кислоты в замкнутом цикле переработки глиноземсодержащего сырья с использованием кислотно-солевого разложения}

\author{
Хамизов Р.Х. ${ }^{1,2}$, Власовских Н.С. ${ }^{1}$, Морошкина Л.П. ${ }^{1}$, КрачакА.Н. ${ }^{2}$, \\ Груздева А.Н. ${ }^{2}$, Хамизов С.Х. \\ ${ }^{l}$ ООО «НьюКем Текнолоджи», Москва \\ ${ }^{2}$ Институт геохимии и аналитической химии им. В.И. Вернадского Российской академии наук, \\ Москва
}

Представлен краткий обзор и критический анализ кислотных и кислотно-солевых методов для переработки глиноземного сырья, включая бокситы с высоким содержанием кремнезема, нефелиновый концентрат и глины. Показаны основные подходы к созданию безреагентных и малореагент- 
ных процессов. Результаты, полученные в ходе долгосрочных систематических лабораторных и стендовых исследований, показывают перспективы создания новых технологий для производства глинозема из бокситов с высоким содержанием кремнезема и алюмосиликатов с использованием различных нитратных и сульфатных реагентов. Показано, что при применении кислот для их возврата в голову процесса и для обеспечения мягких условий для удаления компонентов железа успешно используется сорбционный метод «Удерживание кислоты» в нанопористых средах. Показан циклический процесс, в котором в каждом цикле извлекается и потребляется одно и то же количество солевого реагента. Дано сравнение методов переработки с точки зрения полноты рециркуляции реагентов, качества продукта и сложности процесса. Показаны рекомендуемые условия для производства глинозема из нетрадиционного сырья с разложением кислотно-солевым способом.

Ключевые слова: бокситы с высоким содержанием кремнезема , нефелин, разложение, солевой метод, удерживание кислоты, метод NewChem.

\section{Introduction}

Standard industrial alkaline methods for alumina production (Bayer process and its modifications) require low-silica raw materials which become inaccessible due to the gradual depletion of high-grade bauxite deposits. Using the Bayer process and its analogues for treatment of low-quality bauxites and alumina-silicate materials, such as nepheline, is not advisable from the technological and economic reasons. This is related to many factors including the fact that in the technological process, silica reacts with the alkali, binding a large amount of it, as well as alumina, forming the mixed compound - hydro-aluminosilicates and so leading to their losses [1]. Sintering processes adjoin to the alkaline ones and they consist in sintering raw materials with limestone or limestone and soda or caustic followed by washing final cakes with water or aqueous soda solution. Currently, about $40 \%$ of alumina produced in Russia is obtained from the nepheline of Kola and syenite deposits of Siberia by this method [2]. However, significant limitations of these methods are in high energy consumption and in the need for processing and utilization of large quantities of by-soda-lime-silica products. In the future, at increase in energy prices, the effectiveness of the sintering method can be reduced.

Acid methods, the use of which allows separating the silica already at the first stages of the process without additional inputs of its binding reagents, can become alternative to alkali refining methods [3]. Analysis of the available research results conducted for many decades in Russia, Germany, China and other countries shows major weaknesses of acid technologies. Among them, one can note four major drawbacks:

a) difficulties arise in the creation of closed reagent-free or low-reagent-intake processes.

b) as a rule, these processes are characterized by high energy consumption;

c) supplementary processing and additional steps are needed for iron removal;

d) typically, hard-filterable mixes are formed at acid decomposition.

The first and second of these items are related to the fact that thermo-hydrolysis of compounds containing acid residues and aluminum (as well as iron) is the main approach to "save" and recycle acids in technological circuits. Usually for inorganic salts, thermohydrolysis itself requires high energy. As to the reactant loosing, special difficulties arise at using nitric or sulfuric acid. High-temperature treatment of nitrates or sulfates leads to the emission of nitrogen or sulfur-containing gases, mainly, $\mathrm{SO}_{2}$ or $\mathrm{NO}_{2}$. To save the acids for technological recirculation, these oxides should be chemically transformed into according acids, and this is expensive. Fewer problems arise when using hydrochloric acid [4]. Perhaps, this is the reason why some companies involved in promising developments, in particular, the Orbit Aluminae Co., apply a well-known process of the thermo-hydrolysis of $\mathrm{AlCl}_{3}$ [5]. Finally, there is one serious (but little discussed) problem associated with the irreversible losses of reagents in acid technologies. To achieve high speed and good degree

Khamizov et al. / Сорбционные и хроматографические процессы. 2017. Т. 17. № 6 
of digestion and leaching, it is necessary to use the excesses of acids relative to equivalent amounts of feed components reacting with them. Until recently, it was not known advisable methods for the recovery of these acid excesses to return them into the technological cycle.

Salt methods provide good opportunities for the creation of closed-circular processes. Among them, two best reactants for digestion should be noted: ammonium bifluoride $\left(\mathrm{NH}_{4} \mathrm{HF}_{2}\right)$ and ammonium hydro-sulfate $\left(\mathrm{NH}_{4} \mathrm{HSO}_{4}\right)$. For example, a method [6] is known for processing of alumino-silicates, in particular clay materials, by refluxing them in a solution of ammonium bi-fluoride to obtain a precipitate containing aluminum hydroxide and aluminum fluoride, which is separated, dried and decomposed by steam at to obtain an aluminum hydroxide and recycle of hydrogen fluoride. However, the method has several drawbacks, including the fact that a substantial portion of the original $\mathrm{NH}_{4} \mathrm{HF}_{2}$ is spent; besides it, there are serious hardware requirements which must be stable in the vapor of hydrofluoric acid.

Ammonium hydro-sulfate (bisulfate) process was invented by Max Buchner in Hanover-Kleefeld in 1921, piloted in Germany in the 1920s and in Oregon in 1944. Now this method is included in the list of named processes in chemical technology and is called «Aloton» or «Buchner» [7,8]. The technique consists in implementing circular process comprising the steps of thermal decomposition of ammonium sulfate into ammonia and ammonium bisulfate, dissolving the latter to treat the aluminum-containing feedstock in an autoclave, filtration of solution of alum and precipitating aluminum hydroxide with ammonia, isolation of ammonium sulfate from the mother liquor to return it to the head of circuit. Subsequently, embodiments of the Buchner method appear under which the digestion stage is carried out not by the «wet» process, but by the way of sintering the ammonium sulfate with the raw material [9-11] The process was not commercialized, and it can be assumed that in those days, in the case of good access to high quality raw bauxite materials the Buchner process could not withstand competition with the Bayer one. Moreover, it turned out that the method is suitable for processing readily degradable clay materials and other alumino-silicates, but is poorly applicable to Bauxites [12].

Today, in the new circumstances, it seems appropriate to return to the Buchner process for analyzing its weaknesses and assessing the prospects. This article is devoted to an attempt to solve this problem (yet, at the laboratory level) by combining the capabilities of acid and salt methods and by introducing a previously unknown process stage, called by us «NewChem», which greatly facilitates the creation of real closed-circular schemes for processing high-silica bauxites and alumino-silicate materials.

\section{Experimental}

Three types of alumina-containing raw materials from different deposits of Russia were used: Timan bauxite of hematite-boehmite type; Kaichak kaolin clay and Kola nepheline concentrate. Table 1 shows the contents of macro-components in these materials (bauxite and kaolin work samples, as well as the analytical data on their composition, have been presented by the «Rusal -Vami» Company, S.-Petersburg, Russia; nepheline concentrate has been presented by the NIUIF Institute of the FOSAGRO Co., Moscow, Russia).

Table 1. Chemical composition of raw materials (mass \%)

\begin{tabular}{|c|c|c|c|c|c|c|c|c|c|c|c|c|c|}
\hline & $\mathrm{Al}_{2} \mathrm{O}_{3}$ & $\mathrm{Fe}_{2} \mathrm{O}_{3}$ & $\mathrm{SiO}_{2}$ & $\mathrm{TiO}_{2}$ & $\mathrm{~K}_{2} \mathrm{O}$ & $\mathrm{MgO}$ & $\mathrm{Na}_{2} \mathrm{O}$ & $\mathrm{P}_{2} \mathrm{O}_{5}$ & $\mathrm{SO}_{3}$ & $\mathrm{CaO}$ & $\mathrm{SrO}$ & $\mathrm{MnO}$ & $\mathrm{H}_{2} \mathrm{O}$ \\
\hline Bauxite & 47.7 & 28.3 & 8.0 & 2.8 & 0.63 & 0.39 & 0.23 & 0.22 & 0.20 & 0.17 & - & 0.04 & 11.5 \\
\hline Kaolin clay & 18.3 & 2.7 & 64.2 & 1.7 & 2.0 & 0.89 & 2.1 & 0.15 & - & 0.87 & - & 1.0 & 7.0 \\
\hline Nepheline & 28.0 & 2.4 & 44.0 & 0.55 & 7.6 & 0.45 & 12.5 & 0.17 & - & 1.75 & 0.11 & 0.08 & 1.5 \\
\hline
\end{tabular}


A granulated strong-base anion exchanger, $\mathrm{AV}-17 \mathrm{x} 8$, with quaternary ammonium functional groups and with polystyrene gel type matrix with pores 20-50 nm was used for the elaboration of nano-porous reactor. Acid retardation experiments were carried out with special plastic column containing granulated material and filled with organic liquid immiscible with water and water solutions. One of systems used is shown in Figure 1.A. For the exclusion of ion-exchange processes, anionic resin in nitrate form was used in nitrate media and in sulfate forms - in sulfate ones. Technical-grade reactants including nitric and sulfuric acid, ammonium sulfate, ammonium sulfite and calcium hydroxide were used for the implementation of different stages of processing. Lab-ware glass, autoclave system for 200 bar and vacuum filtering system with removable filtering cloth and disposable filtering papers were also used.
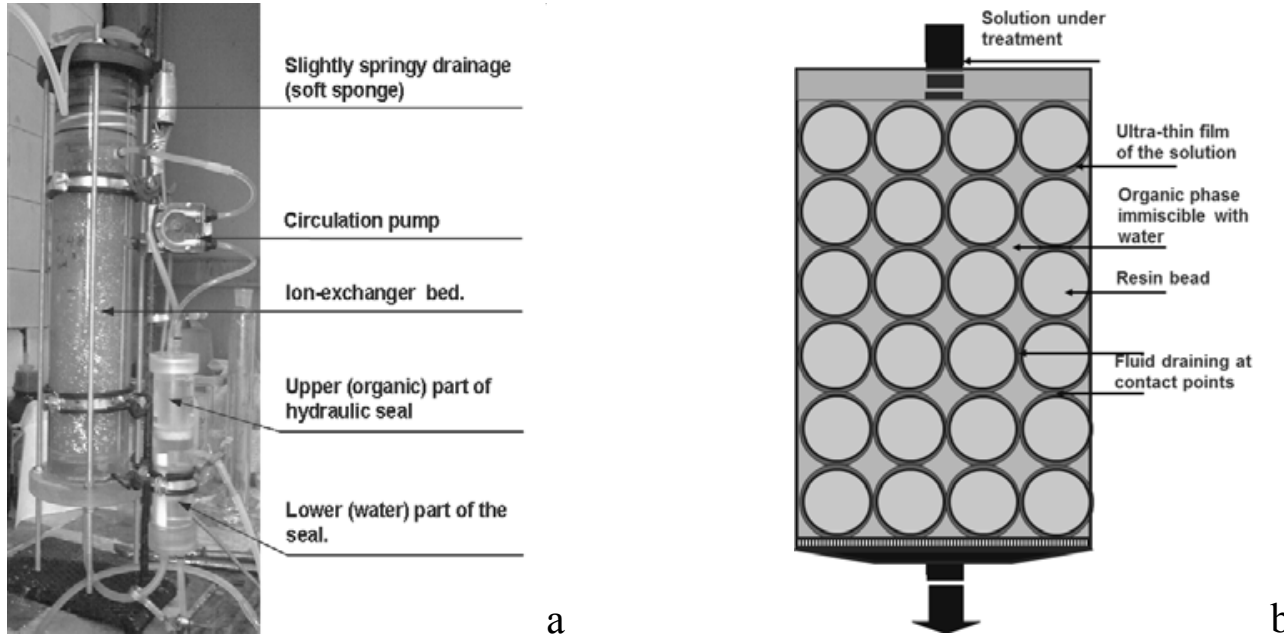

Fig. 1. NewChem system for separation of acids and salts.

a. Photograph of a column (nano-porous reactor) with organic phase. b. Sectional diagram of the column loading

\section{Results and discussion}

\section{Acid Retardation and NewChem approach.}

Let us introduce a proposed separation technique first for acid technology and then transfer it to salt-acid method. To insulate the acid residues from the concentrated media, for example, from mixed solutions of salts of various metals, for the recovery of those acids and recycling them in the head technological process, it is necessary to have a suitable separation method. The principle of such a method was discovered in the early 1960s [13], and it concerned the possibility of separating acids from their salts in highly concentrated solutions on anion-exchangers a ion form similar to the common anion of separated components. The method, called Acid Retardation by its authors, was not based on ion exchange. Today, we know, that anionic resins of gel type can be used owing to their nanosized pores. In concentrated solutions, acids form ion pairs or slightly hydrated molecules that have small sizes and can penetrate into the nano-porous media. At the same time, salts are well dissociated under these conditions to form highly hydrated cations and anions, which meet steric hindrances. Therefore, by passing the dissolved mixture of salts and acid through the column bed, the acid is retained in the bed, and salt thereof, substantially without altering their concentration in the solution, is skipped through the column. The process is cyclic one. In each cycle, the feed solution is passed through the system, which may be called «nano-porous reactor», until the breakthrough, then, almost pure acid is washed by ordinary water and the process is repeated. The method proved to be attractive due to the fact that no reactant is required, just water is used. For a long time, this method did not find 
industrial application due to difficulties in organizing the flow distribution in columns to eliminate mixing of the different substances. Since the late 1970s, after process modifications, it began to be applied and is now widely used, for example, by the Eco-Tec Company (Canada) $[14,15]$. For optimization of the flow distribution in EcoTec columns, they are over-packed, and the interspace between grains is reduced by pressure. Unfortunately, this technology is not applicable to suspensions, turbid work liquors, as well as to supersaturated solutions and colloidal systems.

Our approach consists in reducing the space occupied by water and working solutions in the columns by using an additional liquid phase [16]. The column, loaded with anionic resin or other nano-porous material, is additionally filled by an organic liquid immiscible with the aqueous solutions. No special facilities and no high pressures are required and the ion exchange materials can be used for long time. All the column processes can be carried out in down-flow mode for both salt passing and acid desorption stages of the working cycle. The following interpretation of mass transfer mechanisms in the proposed system can be given. On passing ion containing solutions through a bed of granular ion exchange material in the absence of free space between the grains, as well as under conditions where the organic liquid repels water or the aqueous solution, the latter, being introduced at the interface between the organic liquid and the hydrophilic surface of the granules, forms very thin films enveloping each ion exchange bead and drains by the points of contact between them (Figure 1.B). Such a steady state dynamic system of ultrathin mobile films provides extremely well developed surface area of contact between the phases taking part in the mass exchange process. Owing to the fact that working solutions occupy negligible space volume in the column, there is no possibility of the flows of different substances mixing, and also no problems arise with the choice of direction of these flows. In the case of colloidal systems, they can be freely passed through the column bed, no conditions for growing solid particles and forming large-sized crystals take place. The organic liquid always remains inside the column, but once, a very small volume can be removed on start-up of the column. For hydrodynamic reasons, such a loss can also take place on operation with too high flow rates. However, the lighter organic liquid on leaving the column seeks immediately to go up and can be returned to the column by a tube connecting bottom and top. Such a system is shown in Figure 1. We called the proposed method, «NewChem» from the name of the company which played an important role in its development [16-18].

Consider the effect of using the NewChem method for practical processing of the nepheline concentrate by treatment of the mixed solution produced by nitric acid leaching. Composition of the influent to be processed was (mass \%): $\mathrm{H}_{2} \mathrm{O}-67 ; \mathrm{Al}\left(\mathrm{NO}_{3}\right)_{3}-16 ; \mathrm{HNO}_{3}$ -7.3; $\mathrm{NaNO}_{3}-5.9 ; \mathrm{KNO}_{3}-2.1 ; \mathrm{Fe}\left(\mathrm{NO}_{3}\right)_{3}-1.2$. The problem here is the need to separate acid to return it to the head of the process, thus leading to significant savings in acid.

Figure 2 shows concentration histories for the separation of nitric acid and aluminium nitrate on the nitrate form of the anionic resin. At a sorption stage, the actual liquid concentrate produced by acid leaching of nepheline concentrate was used as the feed solution; acid desorption stage was performed by deionized water. Effluent volumes corresponding to these different stages are separated by vertical solid straight line in the figure. The dashed vertical lines indicate the left and right bounds within which the effluent fractions are to be returned into separating reactor.

There are more interesting properties of the process shown in Fig.2: a) owing to deep separation at acid retardation, the effluent is to be neutral or weakly acidic $(\mathrm{pH}>2$ up to $130 \mathrm{ml}$ ). It leads to the formation of colloidal solution at passing through the bed and to spontaneous precipitation of iron hydroxide within $1-1.5$ hours after column leaving; $b$ ) checking the balance of separated acid shows its amount exceeding the content of the free 
acid in raw solution. It takes place owing to the effect of "soft hydrolysis" which can take place, as follows:

$$
\begin{aligned}
& 3\left[\mathrm{R}-\mathrm{NO}_{3} \cdots \mathrm{H}_{2} \mathrm{O}\right]+\mathrm{Fe}\left(\mathrm{NO}_{3}\right)_{3}=\mathrm{Fe}(\mathrm{OH})_{3} \downarrow+3\left[\mathrm{R}-\mathrm{NO}_{3}{ }^{\cdots} \mathrm{HNO}_{3}\right] \\
& 3\left[\mathrm{R}-\mathrm{NO}_{3} \ldots \mathrm{HNO}_{3}\right]+3 \mathrm{H}_{2} \mathrm{O}=3\left[\mathrm{R}-\mathrm{NO}_{3} \ldots \mathrm{H}_{2} \mathrm{O}\right]+3 \mathrm{HNO}_{3}
\end{aligned}
$$

where: $\mathrm{R}$ denotes the resin group which can be associated with water or acid molecule. Process (1) takes place at sorption stage and (2) - at acid desorption.

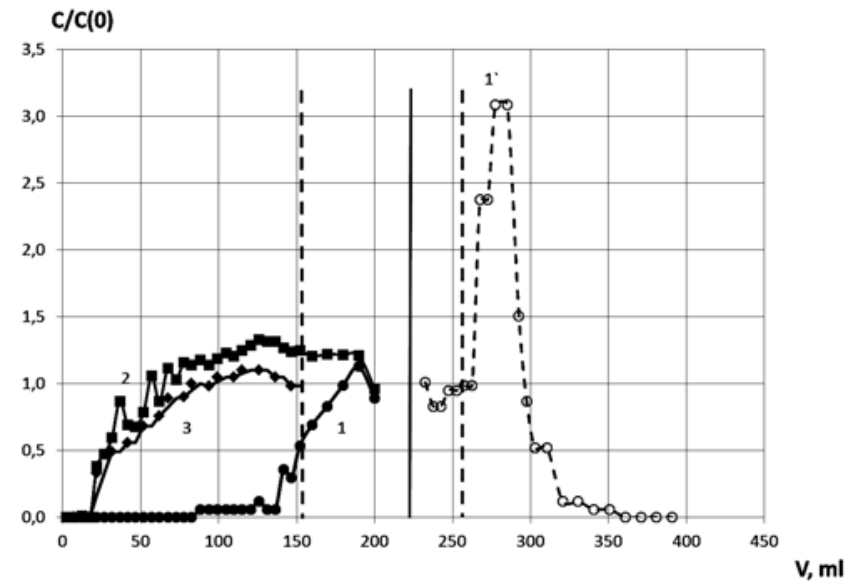

Fig. 2. Break-through concentration curves of $\mathrm{HNO}_{3}$ (1, $1^{`}$ ) and dissolved $\mathrm{Al}$ (2) in one of the repetitive separation cycles of the acid process. 3 - concentration of $\mathrm{Fe}$ in effluent samples before the precipitation of iron hydroxide . Laboratory column loadings: $90 \mathrm{ml}$ of granulated strong base anionic resin $\mathrm{AV}-17$ of gel type in $\mathrm{NO}_{3}$-form. Organic phase - decanol. Flow rate: $2 \mathrm{BV} \mathrm{h}^{-1}$.

Thus, at using acidic digestion technology, the NewChem method allows: returning the residual acid in the process; carrying out additional purification of work solution from iron; carrying out (partially) low-energy consuming process of soft hydrolysis (instead of thermo-hydrolysis) and additional returning the corresponding amount of acid in the process.

Analysis of the Buchner process and salt-acid method.

Let us consider the possibilities of modifying the salt Buchner process to optimize it by the use of NewChem method and other advisable adding to improve. First, we have to state that in both (acid and salt) process types, the mechanism of digestion consists in chemical reaction with acid. Below, this is illustrated by the balance of selected components in a cyclic process:

$$
\begin{gathered}
\mathrm{Al}_{2} \mathrm{O}_{3}+6 \mathrm{NH}_{4} \mathrm{HSO}_{4}\left(3\left(\mathrm{NH}_{4}\right)_{2} \mathrm{SO}_{4}+3 \mathrm{H}_{2} \mathrm{SO}_{4}\right)=2 \mathrm{NH}_{4} \mathrm{Al}\left(\mathrm{SO}_{4}\right)_{2}+3 \mathrm{H}_{2} \mathrm{O}+2\left(\mathrm{NH}_{4}\right)_{2} \mathrm{SO}_{4} \\
2 \mathrm{NH}_{4} \mathrm{Al}\left(\mathrm{SO}_{4}\right)_{2}+6 \mathrm{NH}_{3}+6 \mathrm{H}_{2} \mathrm{O}=2 \mathrm{Al}(\mathrm{OH})_{3} \downarrow+4\left(\mathrm{NH}_{4}\right)_{2} \mathrm{SO}_{4} \\
6\left(\mathrm{NH}_{4}\right)_{2} \mathrm{SO}_{4}=6 \mathrm{NH}_{4} \mathrm{HSO}_{4}+6 \mathrm{NH}_{3} \uparrow
\end{gathered}
$$

In such an ideal pattern, pictured by the reactions (3) - (5), the Buchner process can be fulfilled as the closed-circuit one. Practically, this is hard to be reached at a sacrifice of spending acid for the formation of sulfates of some impurities ( $\mathrm{Ca}, \mathrm{Na}, \mathrm{K}$ ). It is illustrated by the equation (6) for the interaction of ammonium hydro-sulfate with bauxite in an actual process (numerical coefficients reflect the molar ratios of components). Not so much impurities exist in bauxite materials, but the problem can be more serious for different alumino-silicates.

$$
\begin{array}{r}
0.57 \mathrm{Al}_{2} \mathrm{O}_{3} \cdot 0.23 \mathrm{Fe}_{2} \mathrm{O}_{3} \cdot\left(0.12 \mathrm{SiO}_{2} \cdot 0.05 \mathrm{~T}_{\mathrm{i}} \mathrm{O}_{2} \cdot 0.01 \mathrm{MgO} \cdot 0.01 \mathrm{~K}_{2} \mathrm{O} \cdot 0.005 \mathrm{Na}_{2} \mathrm{O} \cdot 0.005 \mathrm{CaO}\right)+ \\
4.8 \mathrm{NH}_{4} \mathrm{HSO}_{4}+17.13 \mathrm{H}_{2} \mathrm{O}+0.03 \mathrm{H}_{2} \mathrm{SO}_{4}=1.14 \mathrm{AlNH}_{4}\left(\mathrm{SO}_{4}\right)_{2} \cdot 12 \mathrm{H}_{2} \mathrm{O}+ \\
0.46 \mathrm{FeNH}_{4}\left(\mathrm{SO}_{4}\right)_{2} \cdot 12 \mathrm{H}_{2} \mathrm{O}+1.6\left(\mathrm{NH}_{4}\right)_{2} \mathrm{SO}_{4}+0.12 \mathrm{H}_{2} \mathrm{SiO}_{3}+0.05 \mathrm{TiO}_{2} \cdot 2 \mathrm{H}_{2} \mathrm{O}+ \\
0.01 \mathrm{MgSO}_{4} \cdot 7 \mathrm{H}_{2} \mathrm{O}+0.01 \mathrm{~K}_{2} \mathrm{SO}_{4} \cdot \mathrm{H}_{2} \mathrm{O}+0.005 \mathrm{Na}_{2} \mathrm{SO}_{4} \cdot 10 \mathrm{H}_{2} \mathrm{O}+0.005 \mathrm{CaSO}_{4} \cdot 2 \mathrm{H}_{2} \mathrm{O}(6)
\end{array}
$$

Khamizov et al. / Сорбционные и хроматографические процессы. 2017. Т. 17. № 6 
Additionally to this problem, it is important to take into consideration that at acid mechanism of digestion, it is advisable to keep some excess of acid in the technological circuit to achieve good kinetics and the extraction degree. Finally, the addition of acid salt reagent and use of salt-acid method leads to the better solution of silica problem.

In a series of experiments, the capabilities of the Buchner salt method were tested for various raw materials, and salt-acid method was compared to it on opening the bauxite of hematite-boehmite type at equal conditions. For temperatures up to $95^{\circ} \mathrm{C}$ the experiments were carried out with open reactors, at more temperatures - with autoclave. The results obtained are shown in Table 2 . They demonstrate the advantages of using minor addition of acid into the salt reagent, especially, at comparison of bauxite digestion with Buchner method and with salt-acid reagent. Similar effect on aluminium leaching degree takes place for the nepheline concentrate. Taking into account that the concentration of acid is too low in the last one, it is advisable to suggest that the visible effect has not thermodynamic, but the kinetic character.

Table 2. The degree of leaching for various alumina sources at the use of ammonium bisulfate and it with small addition of sulfuric acid. $(\mathrm{S} / \mathrm{L}=1: 10$, digestion time - 3 hours $)$

\begin{tabular}{|c|c|c|c|c|c|}
\hline Temperature, ${ }^{\circ} \mathrm{C}$ & $\begin{array}{c}\text { Nepheline } \\
40 \% \\
\text { solution of } \\
\mathrm{NH}_{4} \mathrm{HSO}_{4}\end{array}$ & $\begin{array}{c}\text { Nepheline } \\
40 \% \mathrm{NH}_{4} \mathrm{HSO}_{4} \\
+1 \% \mathrm{H}_{2} \mathrm{SO}_{4}\end{array}$ & $\begin{array}{c}\text { Kaolin } \\
40 \% \\
\text { solution of } \\
\mathrm{NH}_{4} \mathrm{HSO}_{4}\end{array}$ & $\begin{array}{c}\text { Bauxite } \\
40 \% \\
\text { solution of } \\
\mathrm{NH}_{4} \mathrm{HSO}_{4}\end{array}$ & $\begin{array}{c}\text { Bauxite } \\
40 \% \mathrm{NH}_{4} \mathrm{HSO}_{4} \\
+1 \% \mathrm{H}_{2} \mathrm{SO}_{4}\end{array}$ \\
\hline 85 & 48 & 66 & 52 & 18 & 55 \\
\hline 90 & 72 & 95 & 59 & 44 & 58 \\
\hline 98 & 85 & 99 & 59 & 48 & 60 \\
\hline 120 & 98 & 98 & 65 & 60 & 81 \\
\hline 150 & 92 & 100 & 80 & 62 & 86 \\
\hline 175 & 96 & 99 & 87 & 65 & 89 \\
\hline
\end{tabular}

Figure 3 shows the schematic diagram which we proposed and used for salt acid processing of different raw materials.

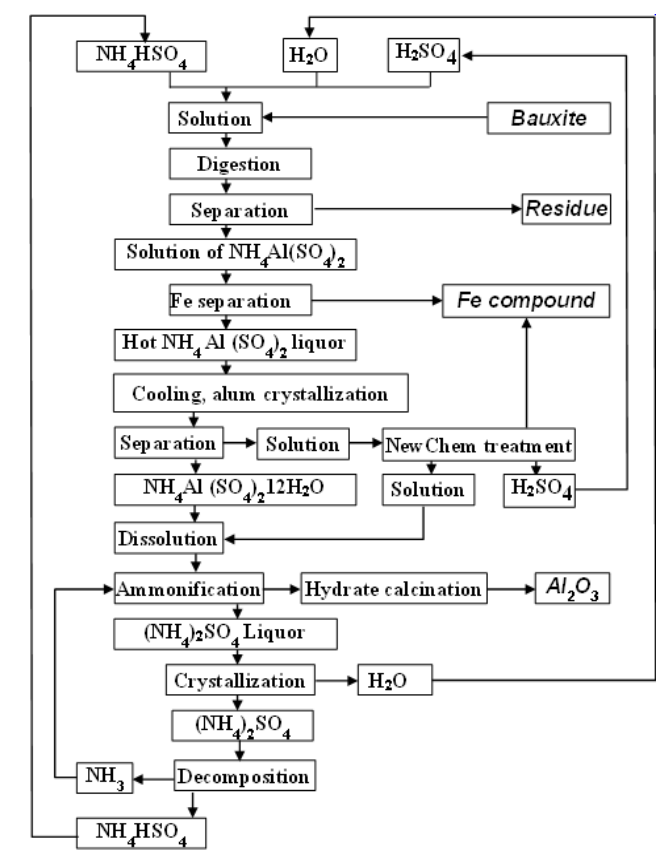

Fig. 3. Flow diagram for salt-acid circular process 
For the simplicity of the diagram not all the stages can be drawn. After the stage of preliminary separation of iron, hot liquor was treated with small amount of ammonium sulfite for reducing Fe(III) to Fe (II), then it was cooled for the crystallization of alum. As it is pictured, the NewChem reactor was used for mother solution after the alum separation.

Some distinction takes in the case of acid separation accompanied by the purification from $\mathrm{Fe}(\mathrm{II})$. The process of spontaneous precipitation of iron hydroxide is relatively slow, and aeration is required for the speedup of the process. The results of the NewChem treatment are shown in Fig.4. The view of concentration curves is similar to that for the acid process described above.

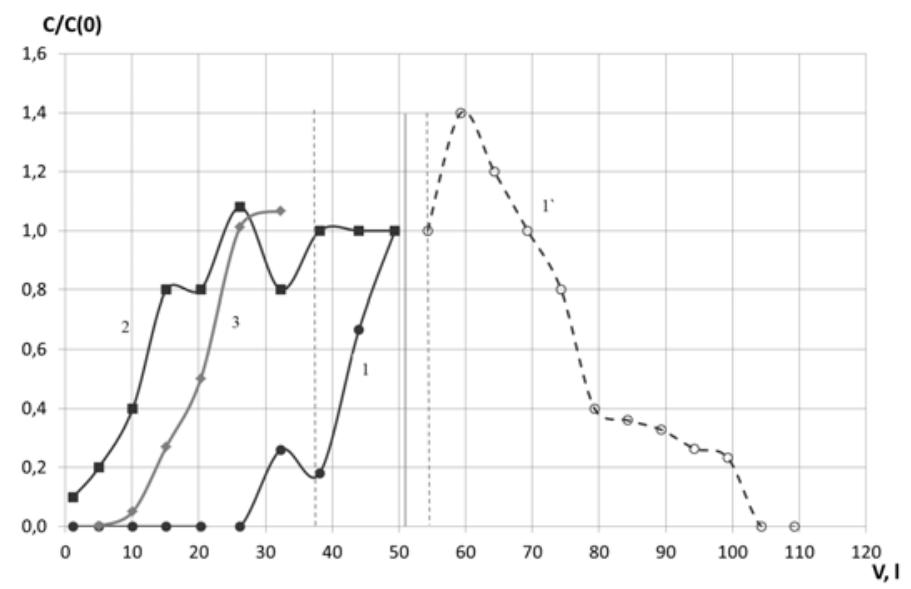

Fig. 4. Break-through concentration curves of $\mathrm{H}_{2} \mathrm{SO}_{4}\left(1,1^{\prime}\right)$ and dissolved $\mathrm{Al}$ (2) in one of the technological cycles. 3 - concentration of $\mathrm{Fe}$ in effluent before the precipitation.

Pilot column loadings: anionic resin AV-17 of gel type in $\mathrm{SO}_{4}$-form.

Organic phase - decanol.

Experimental tests and balance estimations show the feasibility of fully closed cyclic process in the main reagent - sulfate (bisulfate) ammonium. For the production of $1 \mathrm{~kg}$ of the metallurgical alumina in the repetitive technological cycles, the following data on expenses can be given as an example: $2.63 \mathrm{~kg}$ of bauxite; $100 \mathrm{~g}$ of technical grade $(94 \%)$ sulfuric acid; $30 \mathrm{~g}$ of ammonium sulfite; $40 \mathrm{~g}$ of calcium hydroxide; 1.21 of softened water, $7.5 \mathrm{~kg}$ of steam.

\section{Conclusions}

Salt-acid method was proposed, experimentally tested and the closed-circuit process for high-silica bauxite and alumino-silicates was demonstrated.

The NewChem method was introduced and its advantages were shown. They include returning the residual acid in the process; carrying out additional purification of work solution from iron; carrying out low-energy consuming process of soft hydrolysis and additional returning the corresponding amount of acid in the process.

\section{References}

1. Dorre E., Hubner H., Alumina: processing, properties, and applications, Springer London, Limited (2011), p.348, ISBN 9783642823060.

2. Isakov E.A., Tsvetnye Metally (NonFerrous Metals), 1997, No. 4, pp 8-9 (in Russian).
3. Matveev V.A., Theses Diss. Dr. Sciences, Apatity, 2009 (in Russian).

4. Weissenbaeck H., Nowak B., Vogl D., Krenn H., Nickel-Cobalt-Copper Conference of ALTA-2013, 29 May - 1 June, 2013, pp 360- 
362, pub ed. Perth, W.A., Melbourne, Australia, 2013.

5. Patent of Russian Federation 2471010 (2008) / Budro A., Rishar S., Biazotto, F., Method for extraction of aluminum and iron from alumina-containing ores.

6. US Patent 1.426.891, (1922) / McClenahan F.M., Process of recovering metals from silicates.

7. U.S. Patent 1.493.320 (1924)/ Buchner M., Process for manufacturing aluminum hydroxide (British Patent 195,998, Russian patent 11489).

8. Encyclopedic Dictionary of Named Processes in Chemical Technology / Ed.. Comyns Alan E, Boca Raton: CRC Press LLC, 2000, pp.312.

9. Ullmann, B., Encyklopadie der technischen Chemie, Auflage, Urban \& Schwarzenberg, Miinchen \& Berlin, 1954, Bd. 3, pp 401-420.

10.Grim, R.E., Applied Clay Mineralogy, McGraw-Hill, New York, 1962, pp 335-345

11.Bayer G., Kahr G., Mueller-Vonmoos M., Clay Minerals, 1982, Vol .17, pp 271-283.

12. O'Connor D.J., Alumina Extraction from Non-bauxitic Materials, Aluminium-Verlag, Düsseldorf, 1988, pp. 159.

Khamizov Ruslan Kh. - Dr.Sci (Chem), head of the Laboratory of sorption methods, GEOKhI RAS, Moscow, e-mail: khamiz@mail.ru

Vlasovskikh Natalia S. - Ph.D, Head of Laboratory of Physical Chemistry, JSC «NPP «Radiy», Moscow, e-mail: newchemtechnology@mail.ru

Moroshkina Lilia P. - Chemist-technologist, JSC «NPP «Radiy», Moscow,e-mail: $\underline{\mathrm{lm}-}$ $\underline{002 @ \text { mail.ru }}$
13. Hatch MJ, Dillon JA, I\&EC Process Design and Development, 1963, Vol. 2, No 4, pp. 253-263.

14.Brown CJ, Fluid treatment method and apparatus, US Patent No 4673507, June 16, 1987.

15. Sheedy M, Recoflo ion exchange technology. Proceedings of the TMS Annual Meeting held in 1998 in San Antonio Texas,1998.

16.Patent of Russian Federation 2434679 (2011)/ Khamizov R.Kh., Krachak A.N., Podgornaya E.K., Khamizov S.Kh., The method for carrying out sorption mass-exchange processes, apparatus for its implementation, industrial plant for separation of the components of inorganic water solutions and apparatus for the insulation of organic liquids from water solutions.

17.Khamizov, R.Kh., Krachak, A.N., Khamizov, S.Kh., Sorbtsionnye i khromatograficheskie protsessy, 2014, Vol. 14, No 1, pp 14-23

18. Khamizov R.Kh., Krachak A.N., Gruzdeva A.N., Khamizov S.Kh et al., Ion Exchange and Solvent Extraction: A series of Advances, V22/ed. A.SenGupta, CRS Press, N.Y.-L., 2016, pp 147-174.

Krachak Anna N. - Ph.D, Senior researcher, Deputy head of the laboratory of sorption methods, GEOKHI RAS, Moscow, e-mail: krachak@mail.ru

Gruzdeva Aleksandra N. - Ph.D., Senior researcher of the Laboratory of sorption methods, GEOKHI RAS, Moscow, e-mail: alexgruzdeva@yandex.ru

Khamizov Sultan Kh. - Chief Director, LLC «NewChem Technology», Moscow, e-mail: newchem@mail.ru 